\title{
Cristina Dondi
}

\section{"15cBOOKTRADE"}

\author{
AN EVIDENCE-BASED ASSESSMENT AND VISUALIZATION \\ OF THE DISTRIBUTION, SALE AND RECEPTION \\ OF PRINTED BOOKS IN THE RENAISSANCE ${ }^{1}$
}

What books were printed in Venice and exported, purchased, and used in Germany or Poland in the fifteenth century? Or printed in Nuremberg and used in Italy in the 16th century? - What kinds of books? And used by whom? How? - How much did early printed books cost? - Were there any female readers? And what kinds of books were purchased by students, lawyers or priests, in the 15th, 16th or later centuries, in Italy, France or anywhere else? - Which mathematical editions were acquired by religious institutions? Who was buying Ptolemy in the Renaissance? Who was collecting it in the 18 th century? - Can we quantify the amount of $15^{\text {th-century printed books that }}$ entered European and American collections as a direct consequence of the dissolution of religious institutions and their libraries in the 18 th and 19th century? - How many times did Petrarch or Boccaccio appear in print in the 15th century? - What was the percentage of classical, medieval or contemporary texts being published in the first fifty years of printing? - Which works survive today in the largest number of copies? And in the smallest? - Who selected, edited and contributed to the production of a 15th-century edition? - Can we establish the transmission in print of the body of texts that have come down to us via the new medium? - Indeed, how many works were printed in the $15^{\text {th }}$ century (or at least survive today) in single or multiple editions? How many editions contain illustration? Do we have benchmarks that can help us gauge the quality and the quantity of what we have lost over a 500-year period?

1. In December 2013 the author was awarded a European Research Council [ERC] Consolidator Grant for her project: The 15th-century Book Trade: An Evidence-based Assessment and Visualization of the Distribution, Sale and Reception of Books in the Renaissance. The project started on a April 2014 and will continue for five years; see hittp:/www.mod-langs.ox.ac.uk/research/15cBooktrade. A version of the present article in Polish will appear in $Z$ Badan nad Ksiazka i Ksiegozbiorami Historycznymi (= Studies into the History of the Book and Book Collections), published by the University of Warsaw, vol. 7 (2014), http://www.lis.uw.edu.pl/badan/. 
What all these questions have in common is that they are highly relevant to our understanding of the impact of the invention of printing on earlymodern society, and that we cannot answer a single one of them.

\section{INTEGRATING RECORDS FOR RESEARCH: MEI}

Some 30,000 editions of incunabula survive today, in some 450,000 surviving copies, ${ }^{2}$ located in about 4,000 different public libraries, mostly in Europe and North America. Each edition is inventoried in the Incunabula Short-Title Catalogue [ISTC] of the British Library, which also lists the present location of most of the extant copies. The editions are typographically described in the Gesamtkatalog der Wiegendrucke [GW] of the Staatsbibliothek of Berlin. Each surviving copy has a different history, which can be reconstructed with the help of physical evidence (ownership inscriptions, decoration, binding, coats of arms, manuscript annotations, stamps, prices, etc.) and bibliographical evidence (historic library catalogues, bookseller and auction catalogues, acquisition registers, etc.): all this is known as copy-specific information, or provenance, or material evidence, or post-production evidence. Every European and American special collections library is made up of disiecta membra: parts of collections dispersed at some point in the past, often many times over, because of inheritance, sale, donation, exchange, theft, war booty, sequestration, modernisation, neglect, or State policies towards cultural heritage, most notably the suppression of religious institutions and their libraries, which at different times affected most European countries between the 16th and the 2oth century. ${ }^{3}$

2. Figures according to J. Green, F. McIntyre, P. Needham, "The Shape of Incunable survival and statistical estimation of lost editions", in Paper of the Bibliographical Society of America, vol. 105, 2011; pp. 141-75, at p. 147. In 2010 the author and Paul Needham counted manually, from ISTC, the number of surviving copies of some 520 Venetian editions, the equivalent of $14 \%$ of the total number of surviving editions printed in Venice; and concluded that 37 was the average survival rate for copies of Venetian editions, see Cristina Dondi, The Venetian Booktrade: a Methodological Approach to and First Results of Book-based Historical Research, in Early Printed Books as Material Objects (IFLA Pre-Conference, Munich August 2009), ed. Bettina Wagner and Marcia Reed, Munich, Saur, 2010, pp. 221-29. Non-Venetian editions clearly survive in smaller numbers, on the other hand many French copies are still not listed in ISTC, and the count of copies in ISTC at present does not always well distinguish multiple copies of the same edition in the same library. However, part of the 15 CBOOKTRADE project includes the introduction of the copy counter in IST'C which will finally offer a correct picture of the survival of 15 th-century printed books.

3. The "Provenance Index" of the Bodieian catalogue of incunabula [Bod-inc] lists over $4,000(4,054)$ between institutional and private former owners. That of the Houghton Library catalogue, by James Walsh, around 2,650 provenance entries. The same diversity can be found in the 
In the past hundred years, indeed with increased frequency in the last fifty years, ${ }^{4}$ catalogues of incunabula describing their physical features and their provenance in varying degrees of detail, have appeared in a few hundred of paper publications; in more recent years the recording of these physical aspects in libraries' OPAC's has become more and more common. This choice is understandable in terms of collection management, but leads to the fragmentation of provenance records, which in turn makes the use of this valuable information for historical research practically impossible. How can a scholar working on the library of Angelo Poliziano (d. 1494), or the Carthusians of Basel, know that books belonging to that scholar and institution are now in Oxford - or Paris, Liverpool, or elsewhere? How can scholars search every catalogue to pursue the information they are looking for? These provenance records still are, like the books they describe, disiecta membra, scattered in hundreds of paper publications and in hundreds, soon thousands, of electronic library catalogues. Finally, very many copies have still not been catalogued at all, as far as their provenance information is concerned.

If collections are scattered, and so are the records that describe them, consequently, only by integrating their cataloguing descriptions (and offering the same shared space for all those uncatalogued copies) can we attempt to bring them together to study them. It hardly needs underlining that, given this state of the matter, publications on the history of the early book trade have necessarily relied on a tiny fraction of the evidence that does exist, but was until now so hard to use for historical research.

The database Material Evidence in Incunabula [MEI] ${ }^{5}$ was created in 2009 to solve this very substantial obstacle to the use of incunabula as historical evidence: in MEI we are integrating existing provenance records scattered in paper and electronic catalogues, as well as offering a dedicated space for cataloguing the copy-specific aspects of the many thousands of copies in collections, large and small, that have not been catalogued until now. Most importantly, we have created a new way of structuring the provenance information, which enables everybody to finally answer important questions related to the trade and use of 15 th-century books.

British Library, the Bibliothèque nationale de France, the National Library of St. Petersburg, the Morgan Library of New York and, on various scales, in practically every library of the Western world.

4. Lucien Febvre and Henri-Jean Martin, L'apparition du livre, Paris, 2958 (tr. English 1976) not only paved the way for new branches of studies in the history of the book throughout Europe, but, with its reliance on primary sources and physical evidence, inspired and motivated the cataloguing of the material evidence of early printed books in libraries for the following fifty years.

5. http://incunabula.cerl.org. 
86 - Gazette du livre médiéval, $\mathrm{n}^{\circ} 60-2013$.

\section{TRACKING THE MOVEMENT OF BOOKS}

Library collections tend to be perceived as static entities, yet the books they contain, especially those from historic collections, have moved around extensively in their centuries-old existence.

Fig. 1 shows the Bodleian copy of an edition of Aristotle that was printed in Venice, then shipped to Southern Germany where the decoration was added, and where it was used by the Premonstratensians of Weissenau. The book was still in Germany in the 16/17th century, when the still unidentified coat of arms was added, then moved to the United Kingdom in the 19th century.

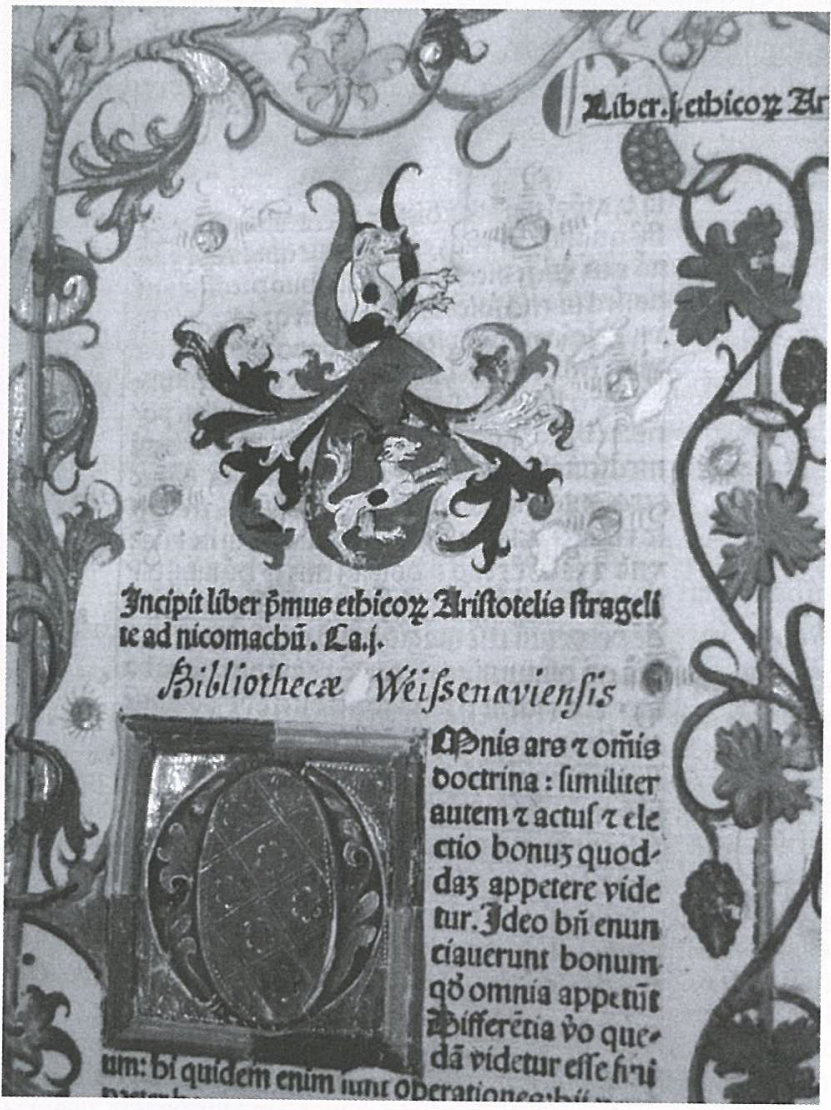

FIG. 1. - Aristoteles, Opera, Venice: A. Torresanus and B. de Blavis (in part for Johannes de Colonia), 1483. Folio. GW 2337; ISTC ia00962000; Bod-inc A-387(1). — Copy: Bodleian Library, Auct. P inf. 1.3, Alr. 
Fig. 2 is from the Oldenburg copy of a book of hours, also printed in Venice, which presents a contemporary German binding and additional manuscript prayers in a German hand (shown here). It must have been shipped soon after production straight to Germany, where indeed the only copy survives today.

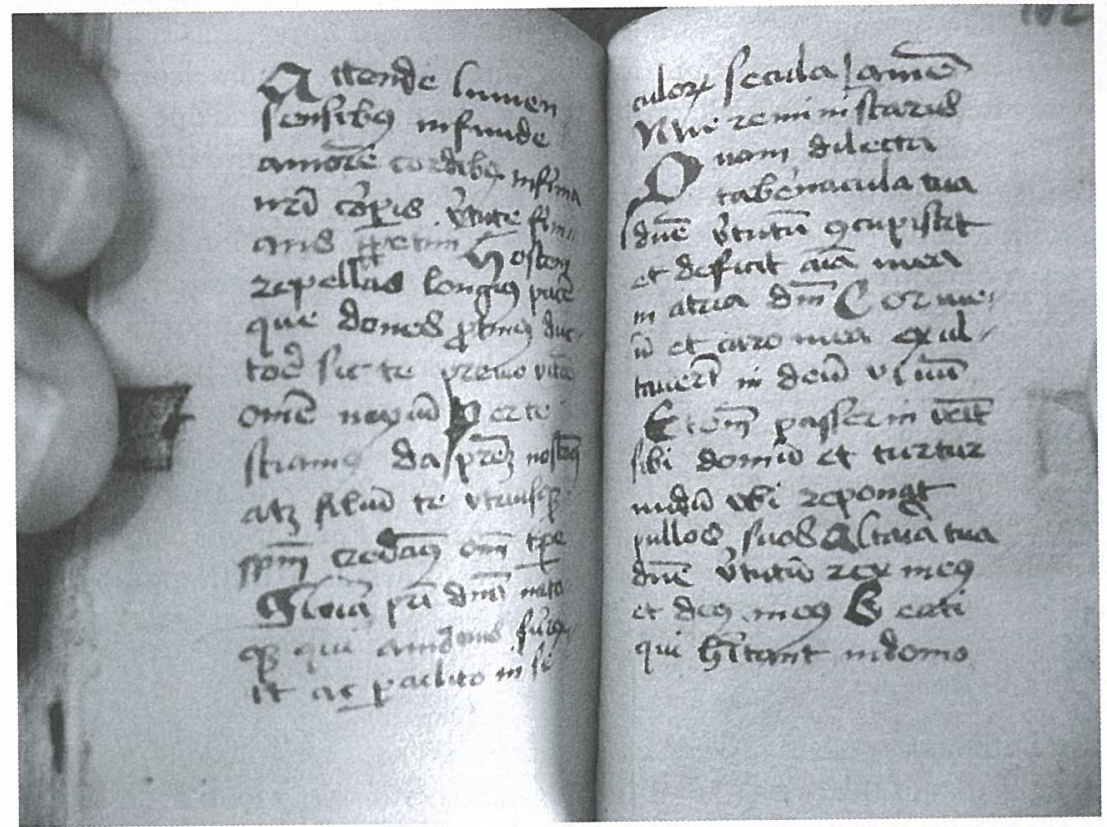

FIG. 2. - Additional handwritten prayers to: Officium B.M.V. secundum usum Romanum, Venice: Georgius Arrivabenus and Paganinus de Paganinis, 1484. 32. GW 13364; ISTC ih00357770. Copy: Oldenburg, Landesbibliothek, CIM II, leaves 161v-162r.

How to capture this unexpressed evidence of the movement of books in time and space, their trade and reception, and process it in chronological and geographical terms? 'The goal was to be able to retrieve the two examples above when querying the database for books printed in Venice and distributed in Germany in the 15th, 16th, or 17th century; for books printed in Venice and collected in England in the 19th century; for books used by religious in the 15 th century, or, conversely, when asking who was buying philosophical works in the 15th century.

The solution was relatively simple: tagging geographically and chronologically every piece of evidence, whether pertaining to a former owner, such as witnessed by an inscription or stamp, or anonymous, such as a decoration and 
binding style or a manuscript hand in the marginal annotations, elements which can be dated and localised by an expert eye.

MEI is a successful international network of contributing libraries from Europe and the US. There are over fifty editors active in MEI, many are wellprepared young scholars with no permanent post yet and cherish the opportunity of working closely with expert scholars and librarians, in a vibrant international community. Contribution of records is free and welcome. There is an interface in English and one in Italian, one in German and one in French will be available shortly. Once in MEI records can be downloaded in MARC21 or UNIMARC Holdings for integration into local OPAC's. MEI was created by the author and developed by Alexander Jahnke of Data Conversion Group, University of Göttingen, with funds from a British Academy Research Development Award [BARDA] granted to Prof. Nigel Palmer and the author in 2009. It is hosted and maintained by CERL and freely available on its website. Over the years further funding was gained by contributing research groups, first of all the team headed by Prof. Edoardo Barbieri of the Centro di Ricerca Europeo Libro Editoria Biblioteca [CRELEB], Università Cattolica of Milan, from public administrations (such as the Regione Lombardia), foundations (such as the Fondazione Cariplo), and the Italian Ministry of Research (PRIN grant).

\section{ONE CASE FOR ALL}

The author was recently asked to present in Florence a new catalogue of incunabula, that of the collection of the Provincial Franciscan house. ${ }^{6}$ In recent years the Florentine library has gathered a number of collections of Franciscan houses from all over Tuscany. Leafing through the useful chapter on provenance marks, where the history of each collection is described and illustrated by vital pictures of their ownership inscriptions, stamps, and former shelfmarks, the author recognised a familiar name: "Libraria di S. Cerbone". The Provenance Index of the Bodleian Catalogue of Incunabula (Bod-inc) does indeed register "Libraria di S. Cerbone (sixteenth century)" but with no further identification. It is found in:

Franciscus de Piatea, Opus restitutionum, usurarum, excommunicationum, Venice: Johannes de Colonia and Johannes Manthen, 22 Jan. 1477. Folio. (GW Moo83i; ISTC ipo0758000; MEI 02005171. Copy: Bodleian Library, Auct. 2Q inf. 2.15; Bod-inc P-337.)

6. Gli incunaboli della Biblioteca provinciale dei Frati minori di Firenze, ed. Chiara Razzolini, Elisa Di Renzo, Irene Zanella, with an essay of Neil Harris, Florence, Regione Toscana, Pacini Editore, 2012. 
At the time of the preparation of Bod-inc we were not able to locate this provenance. Now we know that it belonged to the library of the Franciscans of San Cerbone of Lucca, which was moved to the provincial library of the Franciscans of Florence in the twentieth century. But if one book is now in Bodley, there must be others around. Where? The first call was of course Paul Needham's Index Possessorum Incunabulorum [IPI], now available on the CERL website (http://ipi.cerl.org/), where the author found an entry leading to Yale, ' $\mathrm{N}-273$ ', that is:

Nonius Marcellus, De proprietate latini sermonis, etc. Venice : Antonius de Gusago, 12 Feb. 1498. Folio. (GW M27228; ISTC inoo273000; MEI 02005170. Copy: Yale, Beinecke Library, 1977+187. $)^{7}$

In the Yale copy "S. Cerbone" is also written along the fore-edge, as in a photograph provided in the Florence catalogue. The second call was to look in MEI. A search for "S. C.", one of the ways the library marked their books across the edges, produced a copy in the Houghton Library:

Paulus de Sancta Maria, Scrutinium scripturarum, Mainz: Peter Schoeffer, 7 Jan. 1478. Folio. (GW M29976; ISTC ipoo205000; MEI 02005016. Copy: Cambridge, Houghton Library, WKR 21.6.3; Walsh 19.) [Fig. 3.]

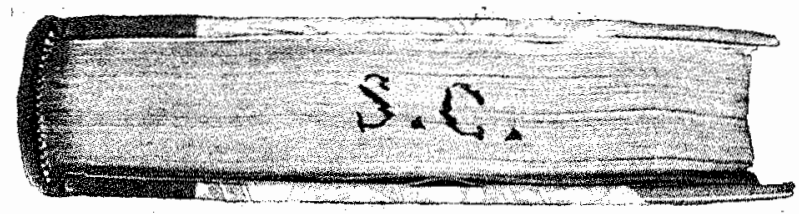

FIG. 3. - Paulus de Sancta Maria, Scrutinium scripturarum, Mainz, 1478 (see text).

John Lancaster is entering into MEI data from Houghton library incunabula originally published in Walsh. ${ }^{8}$ It is a tribute to the thorough recording of the evidence, even that not leading immediately to a clear identification, that the author was able to pick up on this copy's unidentified writing on the edges in an Italian hand. The author then asked William Stoneman for a picture (kindly and immediately supplied by Monique Duhaime) which could be compared with that provided in the Florence catalogue, and will not forget Bill's line in the message by return: "Wouldn't it be wonderful if it was from

7. Elizabeth Frengel kindly helped with the retrieval of their catalogue record from the IPI reference.

8. James Walsh, A Catalogue of the Fifteenth-Century Printed Books in the Harvard University Library, 5 vols, Binghamton(NY), 1991-1997 (Medieval \& Renaissance Texts and Studies, 84, 97, 119, 150, 171). 
San Cerbone if it can't be Sydney Cockerell!"9 The comparison did indeed confirm that the Houghton copy came from San Cerbone of Lucca.

The Houghton copy was purchased by Adolphus Williamson Green (18431917) of New York, then bequeathed by him to his daughter Mrs. Norman P. Ream who donated it to Harvard College Library in June 1951. The Yale copy was purchased in September 1987. However, the Bodleian copy gives us a hint of how these incunabula left the convent early in the 19th century and entered the antiquarian book market. The Bodleian book came into the hands of the Lucca collectors Giacomo (1753-1820) and Cesare (1756-1832) Lucchesini, no doubt as a consequence of the disruptions caused by the suppressions of religious institutions that took place in Tuscany first with Peter Leopold (Grand duke of Tuscany 1765-90) in 1780, then with Napoleon in 1808-10. The bulk of the Lucchesini library was purchased in 1834 by the government of Lucca and incorporated into the public library of the town. However, a number of Lucchesini books must have been sold before that date, as witnessed by the Bodleian copy from San Cerbone, which was purchased for £0.4.6. in 1832 in Florence at an unidentified sale by the Oxford bookseller David Alphonso Talboys acting for the Bodleian Library, together with 16 other editions formerly owned by the Lucchesini. It is therefore very likely that the two American copies were also purchased at the 1832 sale in Florence.

These incunabula are now reunited in MEI where the Bodleian, Yale and Houghton copies, and the 39 editions from San Cerbone now in Florence can be found. Chiara Razzolini, a MEI editor, is describing in MEI all the incunabula of the Biblioteca Provinciale dei Frati Minori of Florence.

It is time for this kind of discovery and research not to be serendipitous, or just so hard and time-consuming, any longer: decades of detailed copyspecific cataloguing, a tool that can bring these valuable data together for research, the awareness of the librarians in charge of these collections of the benefits of integrating data, and the essential work of MEI editors are making it possible. ${ }^{10}$

9. Sir Sydney Carlyle Cockerell (1867-1962) was an English scholar and the director of the Fitzwilliam Museum in Cambridge from 1908 to 1937.

10. This example was discussed in the blog announced by William Stoneman, Curator of Early Books and Manuscripts, the Houghton Library, Harvard University, meaningfully titled Contributing data for greater understanding; it was posted following the lecture and seminar that the present author delivered at the Houghton Library last 7 th and 1oth October 2013; http:// blogs.law.harvard.edu/houghtor/2013/10/11/contributing-data-for-greater-understanding/ 

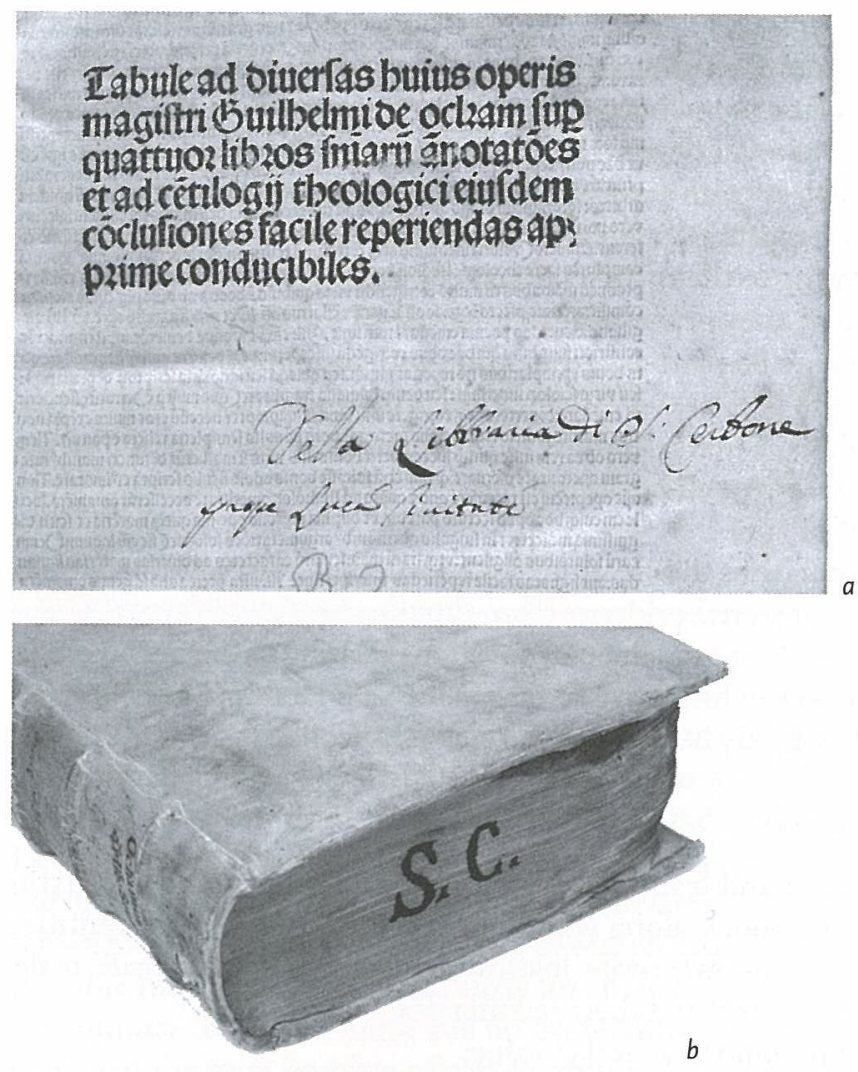

FIG. 4. - Guilelmus Ockam, Quodlibeta, [Lyons: Janon Carcain, c.1488]. 4º (GW 11913; ISTC io00017000.) - Copy: Florence, Biblioteca Provinciale dei Frati Minori, INC.4.3, inscription on $\mathrm{al}^{\mathrm{r}}$ and initials along the upper edge.

\section{FROM MEI TO 15CBOOK'RADE}

In December 2013 the author was awarded a European Research Council [ERC] Consolidator Grant, ${ }^{11}$ for the duration of five years, to develop the project 15CBOOKTRADE: An Evidence-based Assessment and Visualisation of the Distribution,

11. The European Research Council [ERC] is a European funding initiative, designed to support scientists, engineers and scholars in Europe. Its mandate is to encourage the highest quality research in Europe, selected by peer review evaluation, through competitive funding and to support investigator-initiated frontier research across all fields of research, on the basis of scientific excellence. 
Sale, and Reception of Books in the Renaissance. The grant will therefore enable a significant expansion and enhancement of the database MEI, the enhancement of the Incunabula Short Title Catalogue [ISTC], the study of the day-book of a 15th-century Venetian bookseller recording the sale of 25,000 printed books with their prices (with Prof. Neil Harris), cataloguing the incunabula collection of Venetian libraries book in hand, adding to MEI all the provenance records relating to the British Library collection, the creation of a new database to research the corpus of texts printed in the 15th century (modelled on the Bodleian's Bod-inc), experimenting with the application of image-

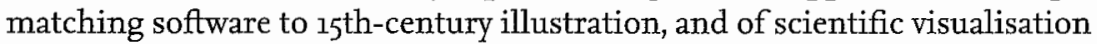
techniques to MEI data, that is applied to the distribution and use of books. Three post-doctoral research positions and one DPhil will commence work in the second half of 2014.

The idea that underpins the creation of MEI and the ERC Project $15 \mathrm{cBoox}-$ TRADE is to use the material evidence from thousands of surviving 15th-century books to address four fundamental questions relating to the introduction of printing in the West which have so far eluded scholarship, partly because of lack of evidence, partly because of the lack of effective tools to deal with existing evidence.

These questions are:

(1) the distribution and trade routes, national and international, of $15^{\text {th- }}$ century printed books, along with their reception, that is the identities of the buyers and users (private, institutional, religious, lay, female, male, and their professions) and their reading practices;

(2) the books' contemporary market value;

(3) the transmission and dissemination of the texts they contain, their survival and their loss;

(4) the circulation and re-use of the illustrations they contain.

\section{DisTRIBUTION AND USE}

With reference to the distribution and use of Venetian books, a first pilot investigation was researched and published by the author in $2008 .^{12}$

It was based on the 1,123 Venetian editions (a third of the total) in 1,387 copies of the Bodleian Library, and their descriptions, provided by the Bodleian Catalogue of incunabula [Bod-inc]. ${ }^{13}$ In the pilot, and now in the MEI database,

12. C. Dondi, “The Venetian Booktrade..." as note 2.

13. Now available online at http://incunables.bodleian.ox.ac.uk/. The genesis of the incunabula collection of the Bodleian library defines it as a small European sample. It is largely a creation of the 
evidence for the distribution and use of the books was collected not only from explicit ownership inscriptions, but also from the decoration, bindings, manuscript notes, and later provenance history of the books. But then the author had to read through every single entry, extrapolate, and re-distribute the information in spread-sheet format, according to the geographical and chronological clues that physical details were offering as evidence of distribution and use. The distribution of Venetian editions in the 15th and 16th centuries, based on the Bodleian sample, could be summarised as following:

\begin{tabular}{|l|c|c|}
\hline Place of use & Number of copies & Percentage \\
\hline UK & 183 & $13 \%$ \\
\hline Germany & 263 & $19 \%$ \\
\hline (sub-total) & $(446)$ & $(32 \%)$ \\
\hline Italy & 481 & $34 \%$ \\
\hline Other & 46 & $3 \%$ \\
\hline Mss Notes (not localised) & 232 & $16 \%$ \\
\hline No Information & 194 & $14 \%$ \\
\hline
\end{tabular}

When assessing the Venetian book trade, it is very important to note that the internal and local distribution - to other parts of Italy and within Venice itself - is as substantial as the international trade, because it is a matter of fact that the international book trade of the city has completely overshadowed the internal market in the perception of scholarship. To my surprise, the systematic way in which material evidence was recorded into Bod-inc. had made possible the localisation of the early use, hence of the distribution, of some 572 volumes for which there was no ownership note as such, the equivalent of $41 \%$ of the total number of copies printed in Venice now in the Bodleian Library. This included some 232 volumes (16\%) for which a localisation of the country of use could be assigned on the basis of marginal manuscript annotations alone, that is on palaeographical grounds, though that was not done by Bod-inc. In total, the author gathered early provenance data for $86 \%$ percent of the examples, that is, 1,205 copies out of 1,387 . Only 194 copies (14\%) did not provide any form of localisation.

The Bodleian incunabula are not exceptional in the preservation of historical evidence relating to their use (rarely will an object with over 500 years of history carry no sign of its life), the Bodleian catalogue is exceptional in taking notice of that evidence to great detail and systematically. Yet catalogue entries by themselves are only the beginning of research. The author needed

late 18 th and 19th century, the result of large-scale acquisitions from dispersed private and institutional continental collections, many from dissolved religious houses. 
to re-arrange in spread-sheets the information extracted from the catalogue entries according to geo-temporal coordinates to make them express the historical content that the books embody and the catalogue registers. A very timeconsuming task which, unsurprisingly, one does not see performed often.

This investigation alerted the author to the necessity of a system to process efficiently the information available, a system that would be able to record and process these "anonymous indicators" (a binding or decoration style, the localisation of the hands in marginal notes) of invaluable historical relevance for the circulation and trade of the books which preserve them. What over ten years spent hands on the incunabula of the Bodleian library, and in several other libraries, taught the author is that the evidence is plentiful, but, crucially, it needs to be not only carefully gathered - and we refer here to good conventional cataloguing, whether on paper or electronic -, but intelligently retrieved.

What the Aristotle's entry looks like in MEI:is shown on Fig. $5^{14}$. Book owners are further characterised by gender, status (religious or lay), and profession (physician, lawyer, politician, clergy, schoolteacher, business, scholar, university lecturer, student, civil servant, bookseller etc., librarian), and type of institution (university, business, academy, book trade, school, municipality, library). Their role is specified: annotator, bookseller, donor, former owner, present owner, librarian, notary. The method of acquisition can also be captured: by purchase, donation, bequest, exchange, institutional transfer (that is as a consequence of the secularisations).

There is a dedicated space for keeping track of the type of provenance evidence used for the dating and localisation: coat of arms, genealogical tables, supralibros, ex libris, mottos, emblems, stamps, firestamps, binding, decoration, manuscript notes, bibliographical evidence, shelfmarks. We can therefore easily ascertain how much of the former ownership of our heritage can be traced because of bindings, notes, or any of the categories just listed.

Elements of decoration are classified according to: illustrations coloured in by hand, illuminations, ornamental letters, pen initials, coats of arms, rubrication, illustrations stamped in. Rubrication notes and their date are individually recorded.

Marginal manuscript annotations are quantified (occasional, a few, several, throughout, extensive), and qualified: corrections, completions, supplements, extraction of key words, collation, translation, structuring the text, comments,

14. The first part of the record, not shown here, contains bibliographical information directly derived from the Incunabula Short Title Catalogue [ISTC]. 
96 - Gazette du livre médiéval, $\mathrm{n}^{\circ} 60-2013$.

censorship, reading marks - that is underlining and pointing hands - drawings, corrections/notes by the printer, lecture notes.

Finally stamps, historical shelfmarks ${ }^{15}$ and prices are also individually recorded.

Needless to say, each of the categories just described can be searched individually and in combination with the others, as well as in combination with the bibliographical data from ISTC: all books printed in Paris with rubrications, all books with censorship notes, all Paris editions with 16th-century bindings, etc.

In MEI, wide-ranging intelligent research on the physical evidence of books can be conducted because it innovates traditional cataloguing in three ways:

- converting and quantifying physical evidence into historical evidence;

- capturing the circulation of books, as evidence of trade and use;

- integrating into one searchable environment existing data from different sources: paper catalogues, newly collected books in hand, and, soon, electronic records, to enable the systematic investigation across institutional and national boundaries.

According to a count of October 2013, there were already c. 3633 editions in 6,575 copies, mostly records created book in hand. You can read all about it in the MEI pages. ${ }^{16}$

Of course all provenance evidence gathered in MEI is automatically fed into the CERL Thesaurus [CT], thus contributing in real time to the reconstruction of dispersed collections, which is one of the main goals of the CT database.

\section{THE CONTEMPORARY MARKET VALUE OF 15TH-CENTURY PRINTED BOOKS}

The most groundbreaking new evidence for the history of the book trade in the 15th century will come from the detailed study of the manuscript Zornale or day-book of Francesco de Madiis. ${ }^{17}$ It records the daily activity and sales of a Venetian bookshop from May 1484 to January 1488 , as well as the inventory of the stock-in-trade for just over one year, to June 1485 . In this period 11,100 entries with their prices are registered, involving 6,950 sales, sometimes

15. MEI cataloguers are progressively putting together a Pattern of historical shelfmarks table, to allow the identification of anonymous old library marks. See http://www.cerl.org/help/incunabula/ shelfmark_patterns.

16. http://www.cerlorg/resources/mei/main.

17. Venice, Biblioteca Nazionale Marciana, MS Ital. XI, 45 (7439), 160 leaves. 
gifts or barters, and over 25,000 copies. For its scale, for its detail and for its importance as a fly-on-the-wall documentary of what happened in a Renaissance Venetian bookshop, the Zornale is unique. Other documentary evidence for the period is piecemeal and of varied nature, such as post-mortem inventories of bookshops and lawsuits that contain estimates of value, but not actual prices. The detailed study of this exceptional document will finally bring to the attention of scholarship previously undocumented economic aspects of the introduction of printing in the West.

Scholars working on any area of classical through to early-modern texts (from school and devotional books to legal, medical, theological, classical publications, etc.) will find here evidence of sales records, hence the reception and market value, of works they are studying, coming from a source both authoritative and representative, a major bookselling outlet in the heart of the most important printing city of the 15 th century. In MEI prices and currencies are also individually recorded, to gather for the first time directly from the books a critical mass of evidence which will be effectively compared with the documentary evidence recorded in the Venetian ledger.

A complete transcription of the original document with an accompanying critical apparatus is being prepared by the author in collaboration with Neil Harris, Professor of Bibliography and Library Studies, University of Udine. It is expected that this work will take four years to complete.

\section{THE CORPUS OF TEXTS PRINTED IN THE 15TH CENTURY:}

TEXT-INC

To be able to work on the transmission and dissemination of texts effectively, we first need to improve our knowledge of the texts that were printed in the 15th century. The project will achieve that by operating on two levels. First we need to set out the precise contents of 15 th-century editions, to be able to establish, for each work, its transmission in print. Second, we need to be able to assess what was printed in the $15^{\text {th }}$ century in more sophisticated terms, by adding to all editions listed in ISTC new coordinates such as lay/religious, subject categories, and time periods.

We still cannot answer such fundamental questions as how many times, when and where Cicero or Petrarch were printed in the 15th century, because some of their works were often included as secondary texts in editions which appeared under the heading of other authors and are so catalogued today. We cannot place in the appropriate socio-historical context the preparation of medical or legal or classical editions, the publication of which was the 
collaborative work of printers and scholars, and often their students, whose interventions are only documented in secondary textual material, such as letters and verses, normally not recorded in catalogues. Nor can we fully document the link with the political and ecclesiastical establishment, as again, this information is often enclosed in dedications and letters included in early editions.

Moreover, the complete analysis of the contents of editions is essential to the study of the transmission of texts in print (stemma editionum) and of their dissemination, as masterfully shown by the publication of the works of Thomas Aquinas by the Leonine Commission ${ }^{18}$ or by the transmission in print of the Facetiae of Poggio Bracciolini studied by Lotte Hellinga. ${ }^{19}$ However, the transmission of texts in print is still too seldom studied, mostly because of lack of adequate resources.

2005 saw the publication of the six volumes of A Catalogue of Books Printed in the Fifteenth Century now in the Bodleian Library [Bod-inc] which provided ground-breaking textual descriptions and identifications for over 5,500 editions. ${ }^{20}$ The catalogue is currently being converted into a database by the Bodleian Library. ${ }^{21}$ It is therefore the perfect opportunity, while the database is still being developed, to set up an extension of it ready to include the content of editions not in the Bodleian and therefore not yet described to the same high standard. This new database, which we will call TEXT-INC, will offer a corpus of all texts printed in the 15 th century and provide one platform for the storage and access of this highly valuable data, linked to ISTC and MEI. Because all the texts described in TEXT-INC will be linked to ISTC (that is, to the edition they belong to), and ISTC is linked to MEI (which describes the ownership and use of the copies of editions), it will then become possible to track the dissemination and reception of printed works using MEI, by examining by whom, where, when and how the copies of the edition were used.

As with the MEI database, TEXT-INC will be a collaborative enterprise, where scholars and librarians will be able to contribute data from the editions they are working on or cataloguing. A project team member will coordinate the inputting of data, as well as analyse the contents of editions now available in digital form on the internet.

18. Sancti Thomae Aquinatis doctoris angelici Opera omnia [...] cura et. studio Fratrum Praedicatorum, Rome, 1882--.

19. Lotte Hellinga, "The Codex in the Fifteenth Century: Manuscript and Print", in A Potencie of Life: Books in Society, ed. N. Barker (The Clark Lectures $1986-19 \delta$ ), London, The British Library, 1993, pp. 63-88.

20. A PDF version of the printed catalogue is available on: http://www.bodleian.ox.ac.uk/bodley/library/ specialcollections/rarebooks/bodleian_incunable_catalogue.

21. http://incunables.bodleian.ox.ac.uk/. 
The second way in which this project will significantly advance our knowledge of what was printed and circulated in the 15 th century is by adding to all editions listed in ISTC new research coordinates such as lay/religious, subject categories, and time periods. The goal is to enable scholars and researchers worldwide to answer questions that have been so far impossible to tackle, such as the percentage of production of any subject, overall and in different countries; the amount of religious versus lay production; the shares of classical, medieval, and contemporary works printed in the first fifty years. This analysis has already been prepared for $90 \%$ of editions in ISTC, by Ezio Ornato (Laboratoire de médiévistique occidentale de Paris [LAMOP]), Chiara Ruzzier and Xavier Hermand (University of Namur), as part of a project which resulted in the publication of Les stratégies éditoriales à l'époque de l'incunable : le cas des anciens Pays-Bas (Turnhout: Brepols, 2012; Bibliologia, 33). The data, unpublished and in spread-sheet form, has been made available to the author for inclusion into ISTC, so that similar research will become possible for the production of all European countries involved with the press in the 15th century. Moreover, by introducing these categories to ISTC we will foster much needed consistency of analysis, avoiding individual scholars producing their own, different, categories.

A project team member based at the British Library will work on the application of these categories with the support of the author and of the board of advisors. ${ }^{22}$

With regard to the survival and loss of 15 th-century printed books, the project will finally enable the introduction of an ongoing counter of copies in both ISTC and MEI, to establish how many copies of a certain edition exist today. This will allow scholars to evaluate what has survived and at the same time better understand what has perished, in relation to authors, titles, formats, language, illustration, and its distribution and reception.

22. The international board of advisors, specialised in 15 th-century printing history and illustration, palaeography, codicology, textual history and the history of libraries consists of: Prof. Richard Sharpe, Prof. Nigel Palmer and Dr. James Willoughby, University of Oxford; Dr. John Goldfinch and Dr. Kristian Jensen, the British Library, London; Dr. Martin Davies (former incunabulist of the British Library), London; Dr. Ezio Ornato, CNRS Paris; Dr. Monique Hulvey, Bibliothèque municipale, Lyon; Prof. Neil Harris, University of Udine; Dr. Dorit Raines, University of Venice; Dr. Marina Venier, Biblioteca Nazionale Centrale, Rome; Dr. Falk Eisermann, Gesamtkatalog der Wiegendrucke, Berlin; Dr. Alex Jahnke, DCG, University of Göttingen; Dr. Bettina Wagner, Bayerische Staatsbibliothek, Munich; Prof. Lilian Armstrong, Mildred Lane Kemper, Professor of Art Emerita, Wellesley College; Dr. Paul Needham, Princeton University. Finally the project is looking for a suitable economic historian to complete the advisory team. 


\section{THE CIRCULATION OF 15TH-CENTURY ILLUSTRATION}

The study of 15th-century illustration is very ill served by the tools currently available. There is a need to track the re-use, exchange, and copying of woodcuts to better understand the working practices of printers and to highlight otherwise undocumented links among them; also, to expand the investigation beyond national boundaries to detect the international borrowing and copying that did take place.

The Department of Engineering Science at Oxford recently devised a software of image-matching to detect the re-use and copying of 17th-century English Ballads held in the Bodleian Library. ${ }^{23}$ To be able to implement this promising technology on 15 th-century illustration we first need to gather the images and to provide them with searchable metadata. Work in this direction has already started in various countries, Germany, the Netherlands, and France. ${ }^{24}$ For this purpose a DPhil student in Oxford will work on capturing Venetian illustration and producing metadata, to test an application which, if successful as hoped, could be easily extended to all 15 th-century illustration. ${ }^{25}$

\section{VISUALISING THE DISTRIBUTION AND USE OF BOOKS AND THE CIRCULATION OF TEXTS}

The objective behind MEI has always been the visualisation of the circulation of books and of the texts they contain, throughout Europe and beyond. This innovative approach has been thought out by the author in order to better understand the trade routes of 15 th-century books. For that purpose, all provenance data is geo-coordinated and chronologically tagged.

Geographical visualisation will be used by the project to communicate effectively the investigation on the trade networks of the editions printed by a certain printer (e.g. where was the Venetian printer Nicolas Jenson exporting to, and how?), or by a certain town (e.g. trading routes of the Venetian book trade), or of a certain work (e.g. production and reception of Pliny's Natural History), or subject (e.g. production and reception of editions of canon law). The goal of combining geographical and chronological visualisation to track

\section{3. http://imagematch.bodleian.ox.ac.uk:80oo/pageo.}

- 24. Searchable images or metadata, or both, have been gathered by the Staatsbibliothek in Munich, the Royal Library in The Hague, and the Bibliothèque nationale de France in Paris.

25. Further data and picture gathering on Venetian illustration will be conducted by Clementina Piazza during a $\mathrm{PhD}$ programme at Birkbeck College, London, supervised by Dr. Filippo de Vivo and co-supervised by the author. 
the movement of objects through time appears to be still a challenge. In collaboration with the Oxford e-Research department, the project will apply scientific visualisation techniques to MEI data, to be able to represent the circulation of books: a successful outcome will benefit scholars in the humanities community at large.

These are exciting times for the study of early printed books. The collaboration of scholars, librarians, and IT, the strength of CERL, is producing fantastic results which are finally laying the ground for some very interesting new research. Extensive evidence-based data will soon form the content of up-to-date studies on the history of early printing in Europe, to be used by historians to discuss, evidence in hand, the impact of printing on the social, economic, intellectual and scholarly development of society in Europe and the Americas.

\section{Cristina DONDI}

Oakeshott Senior Research Fellow in the Humanities, Lincoln College, University of Oxford cristina.dondi@mod-langs.ox.ac.uk 